\title{
Biological determination of inhibin in rat ovarian-cell culture medium
}

\author{
France Croze* and P. Franchimont \\ Laboratoire de Radioimmunologie, Institut de Pathologie, C.H.U., Bât B 23, Université de Liège, \\ Belgium
}

\begin{abstract}
Summary. Rat ovarian-cell culture medium contains steroids and inhibin material that are able to influence basal and LHRH-stimulated secretion of FSH and LH from dispersed pituitary cells. Studies on procedures to remove steroids, such as ethyl acetate extraction and charcoal:dextran adsorption, showed that adsorption of the culture medium with 0.5 to $1.0 \%$ charcoal and 0.05 to $0.1 \%$ dextran, respectively, was the optimal method to eliminate most of the steroids in the medium without a detrimental effect on inhibin activity. The inclusion of serum or bovine albumin in the culture medium after the culture protected the inhibin from adsorption by the charcoal:dextran treatment. The inhibin present in the rat ovarian-cell culture medium treated with $1.0 \%$ charcoal : $0.1 \%$ dextran behaved like the inhibin reference standard (from rete testis fluid of the sheep: RTFS) in the basal secretion of FSH and the LHRHstimulated secretion of FSH and LH in the in-vitro bioassay.
\end{abstract}

\section{Introduction}

Granulosa cells secrete steroids and inhibin (Erickson \& Hsueh, 1978; Henderson \& Franchimont, 1981, 1983; Hermans, van Leeuwen, Debets, Sander \& de Jong, 1982) that can influence the secretion of FSH and LH. Some authors have reported that steroids can modify the effect of inhibin on the secretion of FSH and LH in vivo (Campbell \& Schwartz, 1979; Williams \& Lipner, 1980; Miller, Wesson \& Ginther, 1981) and in vitro (Lagace et al., 1979; Shander, Anderson, Barraclough \& Channing, 1980). However, others have not found any alteration by steroid on the inhibitory action of inhibin on gonadotrophin secretion in vivo (Rush et al., 1981) and in vitro (Lagace et al., 1979; Hermans et al., 1982).

From these results, it appears necessary to investigate the respective effects of the steroids and inhibin present in the culture medium of ovarian cells from immature rats primed with PMSG, which we have proposed as a model to study the regulation of inhibin (Croze \& Franchimont, 1984), and to examine methods to remove these steroids from the culture media. Furthermore, we have studied the protective effect of the serum in the culture medium against the adsorption of inhibin by charcoal : dextran treatment.

\section{Materials and Methods}

Inhibin bioassay. The in-vitro bioassay described by Henderson \& Franchimont (1981) was used to measure the inhibitory activity of rat ovarian-cell culture medium on FSH and LH secretion. The dispersed pituitary cells were allowed to attach for $48 \mathrm{~h}$. At this time, the medium was removed and the cells were exposed for 3-4 days to $200-400 \mu \mathrm{l}$ medium from cultured rat ovarian cells used

* Present address: Department of Physiology, Faculty of Medicine, University of Manitoba, Winnipeg, Manitoba R3E 0W3, Canada. 
untreated or treated as described below before the inhibin bioassay. To validate the bioassay for the rat ovarian-cell culture medium, volumes between 4 and $250 \mu 1$ medium were used in the bioassay and compared to $0 \cdot 25,0 \cdot 5,1 \cdot 0$ or $2 \cdot 0 \mathrm{U}$ of the reference standard of inhibin derived from ovine rete testis fluid (RTFS; kindly supplied by Professor B. Hudson). The volume was adjusted to $1 \mathrm{ml}$ with Dulbecco's modification of Eagle's medium supplemented with serum (DMEM $+\mathrm{S}$ ) as described by Henderson \& Franchimont (1981). The reference material and the ovarian-cell culture media were tested in 3-5 replicate wells. After the basal incubation period, the media were removed and the pituitary cells were stimulated with LHRH $\left(10^{-8} \mathrm{M}\right)$ for $6 \mathrm{~h}$ in the presence of the same amount of ovarian-cell culture medium or inhibin material as used during the basal incubation. Medium DMEM without serum (DMEM-S) was used to adjust the final incubation volume to $1 \mathrm{ml}$. The media collected during the basal and LHRH-stimulated conditions were stored at $-20^{\circ} \mathrm{C}$ until assayed for FSH and LH.

Rat ovarian-cell culture medium. Rat ovarian cells were prepared as described by Croze \& Franchimont (1984). The $2 \times 10^{6}$ cells per dish $(60 \times 15 \mathrm{~mm}$ : Falcon, Oxnard, CA, U.S.A.) were generally incubated with $2 \mathrm{ml}$ Ham's F10 medium supplemented with L-glutamine (2 mM), penicillin $(100 \mathrm{U} / \mathrm{ml})$ and streptomycin $(100 \mathrm{~g} / \mathrm{ml})($ Medium $\mathrm{F} 10+$ : Flow Laboratories, Irvine, U.K.) plus $10 \%$ fetal calf serum (FCS) and kept at $37^{\circ} \mathrm{C}$ in an incubator with a gas phase of $95 \%$ air and $5 \% \mathrm{CO}_{2}$ saturated with water.

To study the protective effect of serum or bovine serum albumin against the adsorption of inhibin by charcoal:dextran treatment, the rat ovarian cells were harvested and cultured in Medium F10 + without FCS for 24-48 h. The medium was then collected and filtered to remove cellular debris.

The inhibin activity was measured in ovarian-cell culture medium that was untreated, adsorbed by charcoal (Carbon Decolorizing Neutral Norit: Fisher Scientific Co., Fair Lawn, NJ, U.S.A.) with dextran (Dextran T70, Pharmacia Fine Chemicals AB, Uppsala, Sweden), or extracted with 6 volumes of ethyl acetate (analytical grade, Merck, Darmstadt, West Germany) per volume of ovarian-cell culture medium. The adsorption with charcoal : dextran was performed at $4^{\circ} \mathrm{C}$ for $16 \mathrm{~h}$ with continuous rotation. The media were then centrifuged and filtered on a $0.45 \mu \mathrm{m}$ cellulose millipore filter. The extraction was also performed at $4^{\circ} \mathrm{C}$ and after the 16 -h rotation the ethyl acetate was aspirated, care being taken to evaporate the remaining ethyl acetate under a stream of nitrogen. In one experiment inhibin activity in the ovarian-cell culture media was destroyed by heating the medium at $80^{\circ} \mathrm{C}$ for $1 \mathrm{~h}$.

Radioimmunoassays. The concentration of FSH in the media from cultured pituitary cells was measured in duplicate by a heterologous double-antibody radioimmunoassay using the first antibody raised against ovine FSH (Derivaux, Ectors, Hendrick \& Franchimont, 1974) or the homologous double-antibody radioimmunoassay supplied by the pituitary agency of the NIAMDD. The iodinated rat FSH (NIAMDD, FSH-I-5) was prepared according to the method of Greenwood, Hunter \& Glover (1963). The standard NIAMDD rat FSH-RP1 completely displaced the tracer from the antibody raised against ovine FSH. A coefficient of correlation of $0.95(n=271$, $P<0.001)$ was calculated between the concentration of FSH estimated in the heterologous $(y)$ and the homologous $(x)$ assay $(y=16+1 \cdot 6 x)$. The sensitivity of the heterologous assay was $6 \cdot 3 \pm 1 \cdot 7$ $\mathrm{ng} /$ tube (mean \pm s.d., $n=8$ ) with the within- and between-assay coefficients of variation of $4 \cdot 0$ and $13.4 \%$ respectively $(n=8)$. The assay characteristics of the homologous assay are given by Henderson \& Franchimont (1981).

The concentration of LH in media from cultured pituitary cells was measured by the homologous double-antibody radioimmunoassay supplied by the pituitary agency of the NIAMDD.

The concentrations of progestagens, androgens and oestrogens in ovarian-cell culture media untreated, charcoal : dextran-adsorbed or after extraction with ethyl acetate were measured by the radioimmunoassay described by Croze \& Franchimont (1984). 
Statistical analysis. Unpaired or paired Student's $t$ tests were used when two experimental groups were compared. When the results of several groups were examined, analysis of variance was used in combination with Scheffé's multiple comparison test (Pollard, 1977) to identify the significantly different $(P<0.05)$ experimental groups. The data were transformed to logarithms before the analysis of variance if the variances were judged heterogeneous by Bartlett's test (Steel $\&$ Torrie, 1960). The statistical validation for linearity and parallelism between increasing volume of ovarian-cell culture medium and inhibin standard reference was done by the method described by Borth (1976).

\section{Results}

Study of two methods to remove endogenous steroids

Unexposed culture medium (Medium $\mathrm{F} 10+$ plus $10 \% \mathrm{FCS}$ ) and media exposed to cultured rat ovarian cells and left untreated, adsorbed with $1 \cdot 0 \%$ charcoal $: 0 \cdot 1 \%$ dextran or extracted with ethyl acetate were tested in the in-vitro biological assay for inhibin. These media were also subjected to $80^{\circ} \mathrm{C}$ for $1 \mathrm{~h}$. The results are summarized in Table 1.

The basal secretion of FSH was not changed by the presence of $400 \mu 1$ Medium F10+ plus $10 \%$ FCS however it was treated except when the Medium F10+ plus $10 \%$ FCS was heated after extraction with ethyl acetate then the secretion of FSH was significantly increased. The untreated and ethyl acetate-extracted media from ovarian cell cultures diminished the basal secretion of FSH by approximately 65 and $50 \%$ respectively. A volume-response was not observed for these media and there was no detectable suppression of their activity by heating. In contrast, the ovarian-cell culture medium adsorbed with charcoal : dextran suppressed the secretion of FSH in a volumedependent manner and its inhibitory activity was lost after denaturation of protein by heat.

The basal secretion of LH was not modified by the untreated and the charcoal:dextranadsorbed Medium F10 + plus 10\% FCS. However, a stimulatory effect on the basal LH secretion was observed when this medium was extracted with ethyl acetate. The untreated medium from ovarian cells in culture reduced the basal secretion of LH even after heating, but there was no significant decrease in the secretion of $\mathrm{LH}$ when the ovarian-cell medium was adsorbed or extracted.

The LHRH-stimulated secretion of FSH was not affected by Medium F10+ plus $10 \% \mathrm{FCS}$ whether untreated or charcoal : dextran-adsorbed. Ethyl acetate extraction of Medium F10 + plus $10 \%$ FCS significantly suppressed the LHRH-induced secretion of FSH. A volume-response was measured for the suppression of the LHRH-stimulated secretion of FSH by the untreated medium from cultured ovarian cells and when it was extracted with ethyl acetate. However, heating these two media only partly decreased their inhibitory activity. The ovarian-cell medium adsorbed by charcoal : dextran significantly diminished the secretion of the LHRH-induced release of FSH only when $400 \mu \mathrm{l}$ were used; this inhibition was abolished by heat.

The LHRH-stimulated secretion of LH was unaffected when the Medium F10+ plus $10 \%$ FCS was untreated or adsorbed with charcoal:dextran but was significantly diminished when the Medium F10 + was extracted with ethyl acetate. The LHRH-induced release of LH was decreased in a volume-response manner when the pituitary cells were exposed to the untreated or ethyl acetate-extracted ovarian cell media. The suppression of LHRH-stimulated secretion of LH by the untreated ovarian-cell medium was not significantly influenced by heating, but heating significantly reduced the ability of the ethyl acetate-extracted ovarian-cell medium to suppress the secretion of LH induced by LHRH. There was no significant decrease of the LHRH-stimulated secretion of LH by $400 \mu$ l ovarian-cell medium adsorbed by charcoal : dextran.

Extraction with ethyl acetate removed a greater percentage of progestagens in Medium $\mathrm{F} 10+$ plus $10 \%$ FCS and the ovarian-cell medium than did adsorption with charcoal:dextran but androgens and oestrogens were better removed by charcoal: dextran treatment. 


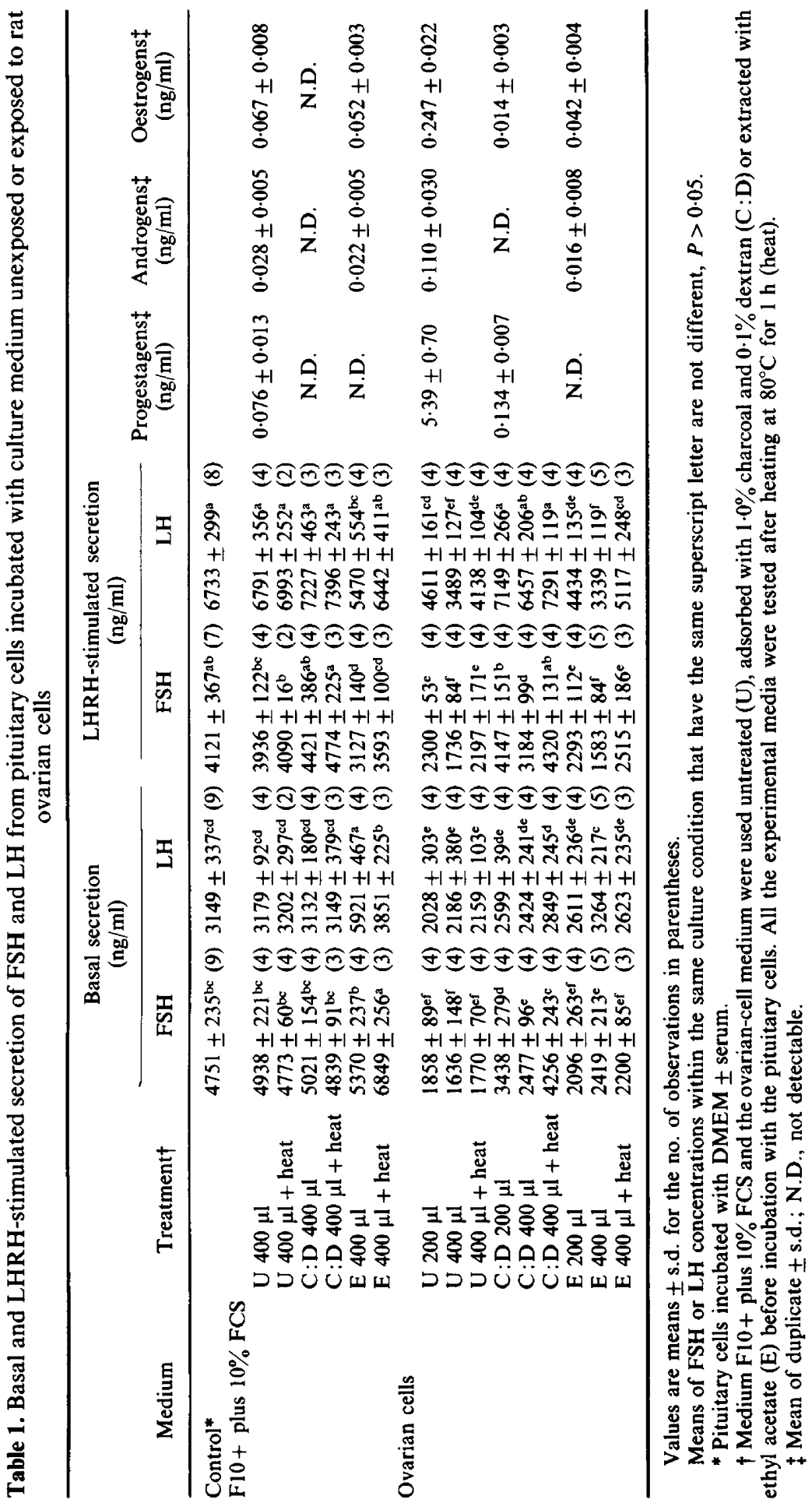




\section{Effect of various concentrations of charcoal : dextran on inhibin and steroids}

Since charcoal:dextran adsorption appears to be an adequate method to remove endogenous steroids, the optimization of the charcoal:dextran procedure was studied. Ovarian-cell culture medium unexposed or exposed to rat ovarian cells was adsorbed by $0,0 \cdot 1,0 \cdot 5,1 \cdot 0,2 \cdot 0$ or $4 \cdot 0 \%(\mathrm{w} / \mathrm{v})$ charcoal with $0,0 \cdot 01,0 \cdot 05,0 \cdot 1,0 \cdot 2$ or $0.4 \%(\mathrm{w} / \mathrm{v})$ dextran, respectively, and was tested in the inhibin bioassay and assayed for content of progestagens, androgens and oestrogens (Table 2).

When Medium $\mathrm{F} 10+$ plus $10 \%$ FCS was adsorbed with increasing percentages of charcoal : dextran there was no inferference with the secretion of FSH or LH, basal or after LHRH stimulation.

The suppression of basal FSH secretion was greatest when the pituitary cells were exposed to ovarian-cell medium adsorbed with $1.0 \%$ charcoal : $0 \cdot 1 \%$ dextran. Intermediate inhibition in basal FSH secretion was measured in culture medium from pituitary cells incubated with ovarian-cell medium adsorbed with charcoal :dextran proportions of $0 \cdot 5: 0 \cdot 05$ and $0 \cdot 1: 0 \cdot 01$. Unadsorbed ovarian-cell medium and medium treated with $2 \cdot 0 \%$ charcoal : $0 \cdot 2 \%$ dextran had significantly lower inhibitory activity on the FSH secretion than did medium adsorbed with $1.0 \%$ charcoal: $0 \cdot 1 \%$ dextran. Inhibition of FSH secretion was also detected when ovarian-cell medium was treated with $4.0 \%$ charcoal $: 0.4 \%$ dextran but the diminution in FSH secretion was much smaller than the inhibition observed with the 5 other groups.

The basal secretion of LH was not significantly reduced by the ovarian-cell medium whether unadsorbed or adsorbed with the various percentages of charcoal :dextran. With Medium F10+ plus $10 \%$ FCS, the LHRH-stimulated secretion of gonadotrophins was not influenced by adsorption with increasing percentages of charcoal: dextran.

The secretion of FSH and LH in the presence of LHRH was lowest when the pituitary cells were exposed to unadsorbed ovarian-cell medium. The suppression of FSH and LH was lower but constant for the ovarian-cell medium adsorbed with percentages of charcoal :dextran between $0 \cdot 1: 0 \cdot 01$ and $1 \cdot 0: 0 \cdot 1$. Adsorption with $2 \cdot 0: 0 \cdot 2$ and $4 \cdot 0: 0 \cdot 4$ charcoal : dextran greatly diminished the suppression of FSH secretion and totally abolished the inhibition of $\mathrm{LH}$ secretion.

From the results presented in Tables 1 and 2, there is a discrepancy in the suppression of the basal secretion of FSH by the ovarian-cell media untreated and adsorbed with $1.0 \%$ charcoal :0.1\% dextran. In a similar study, 5 other ovarian-cell media have been tested untreated or after adsorption with $1.0 \%$ charcoal : $0.1 \%$ dextran (data not shown). The basal secretion of FSH was equally reduced by ovarian-cell medium untreated and adsorbed by charcoal :dextran for 2 media, but was better suppressed by the adsorbed medium, as in Table 2, for 2 media, whilst the untreated medium of the last sample was more effective in inhibiting the basal secretion of FSH than after adsorption by charcoal :dextran. The basal secretion of LH was never affected by these 5 different ovarian-cell media adsorbed with charcoal:dextran. The inhibition of the LHRH-induced secretion of FSH and LH was always greater when the ovarian-cell media were untreated than when they were adsorbed by charcoal: dextran. The difference between the percentage inhibition of FSH and LH in the presence of LHRH was always $>15 \%$ for the charcoal :dextran-adsorbed media; this difference for the untreated ovarian-cell media was $<15 \%$.

The concentration of progestagens, androgens and oestrogens (Table 2) present in Medium F10 + plus $10 \%$ FCS unadsorbed by charcoal:dextran was low compared to that for ovarian-cell media. Adsorption of Medium Fl0 + plus 10\% FCS with charcoal:dextran $\geqslant 0 \cdot 1 \%: 0 \cdot 01 \%$ removed $\sim 60 \%$ of the progestagens and androgens and $85 \%$ of the oestrogens. A large proportion of the endogenous progestagens $(99.2 \%)$, androgens $(93.8 \%)$ and oestrogens $(98.7 \%)$ present in ovarian-cell medium were adsorbed with $0.1 \%$ charcoal : $0.01 \%$ dextran. Greater quantities of charcoal:dextran did not adsorb more progestagens. The concentrations of androgens and oestrogens were near the blank value after adsorption with $2 \cdot 0 \%: 0 \cdot 2 \%$ and $1 \cdot 0 \%: 0 \cdot 1 \%$ charcoal: dextran respectively. 


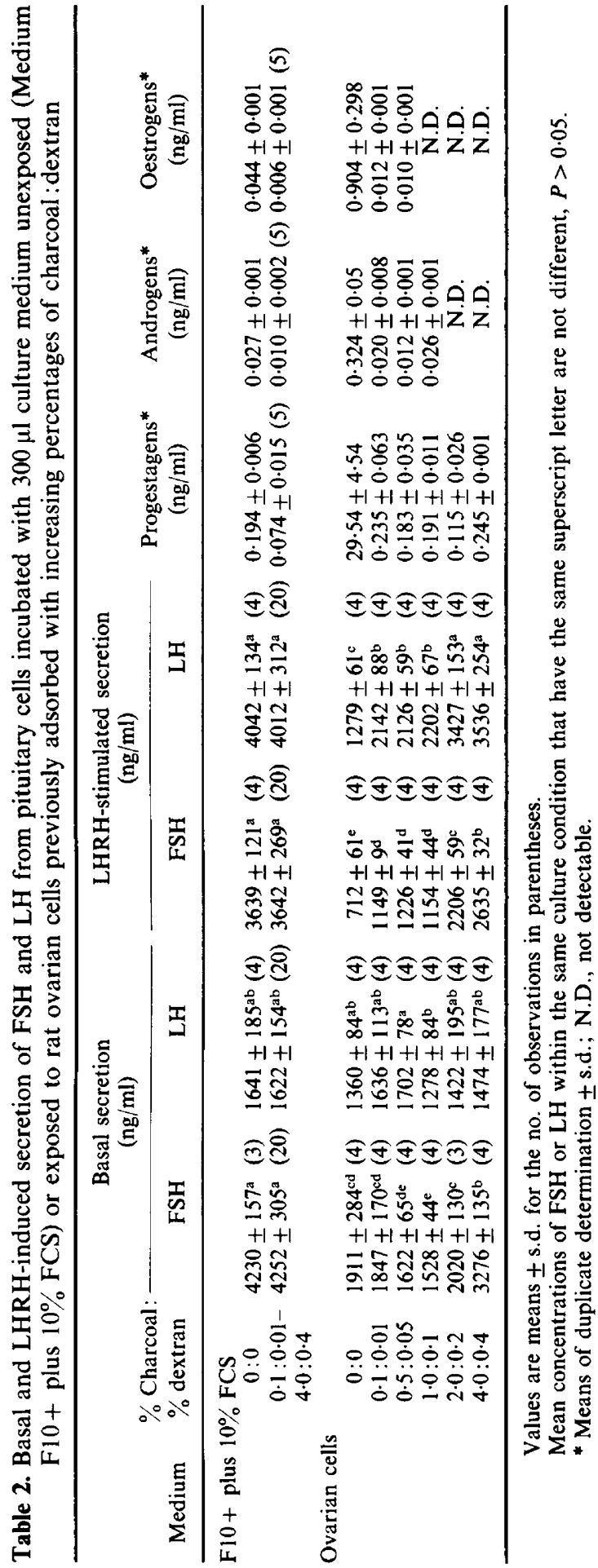


Protective effect of exogenous protein on the adsorption of inhibin by charcoal :dextran

In the previous experiment, adsorption of ovarian-cell culture medium with a high percentage of charcoal : dextran $(2 \cdot 0 \%: 0 \cdot 2 \%$ and $4 \cdot 0 \%: 0 \cdot 4 \%)$ diminished the inhibitory activity on the basal and the LHRH-stimulated secretion of FSH and abolished the inhibiton of the LH secretion induced by LHRH. Several studies on the protective effect of serum and bovine serum albumin (BSA) were undertaken.

In one experiment, culture media from rat ovarian cells incubated without serum were supplemented after the culture with percentages of FCS from $2 \cdot 5$ to $12.5 \%$, left for $24 \mathrm{~h}$, and then adsorbed with charcoal: dextran and tested in the in-vitro bioassay (Table 3 ).

Table 3. Basal and LHRH-stimulated secretion of FSH and LH from pituitary cells incubated with $300 \mu l$ rat ovarian-cell culture medium incubated without serum and then supplemented with various percentages of fetal calf serum (FCS)

\begin{tabular}{|c|c|c|c|c|}
\hline \multirow[b]{2}{*}{ Medium* } & \multicolumn{2}{|c|}{ Basal secretion (ng/ml) } & \multicolumn{2}{|c|}{ LHRH-stimulated secretion ( $\mathrm{ng} / \mathrm{ml})$} \\
\hline & FSH & LH & FSH & LH \\
\hline $\begin{array}{l}\text { Control } \dagger \\
\text { Ovarian cells }\end{array}$ & $2049 \pm 208^{a}$ & $935 \pm 103^{\mathrm{ab}}(8)$ & $1750 \pm 45^{b}$ & $2826 \pm 267^{\mathrm{abc}}$ \\
\hline$+0 \%$ FCS & $1899 \pm 89^{a}$ & $1032 \pm 49^{a}$ & $1892 \pm 70^{\mathrm{ab}}(4)$ & $2896 \pm 236^{\mathrm{abc}}(4)$ \\
\hline$+2.5 \% \mathrm{FCS}$ & $1737 \pm 75^{\mathrm{ab}}$ & $908 \pm 77^{a b}$ & $1922 \pm 64^{\mathrm{a}}$ & $3284 \pm 228^{a}$ \\
\hline$+5.0 \%$ FCS & $1483 \pm 101^{\mathrm{bc}}(4)$ & $963 \pm 127$ & $1714 \pm 47^{b}$ & $3304 \pm 92^{a}$ \\
\hline$+7.5 \%$ FCS & $1200 \pm 58^{\mathrm{cd}}$ & $845 \pm 86^{\mathrm{ab}}$ & $1481 \pm 87^{c}$ & $3157 \pm 101^{\mathrm{ab}}$ (4) \\
\hline$+10.0 \% \mathrm{FCS}$ & $1072 \pm 128^{d}$ & $801 \pm 100^{\text {ab }}(4)$ & $1296 \pm 57^{c}$ & $2643 \pm 27^{b c}$ \\
\hline$+12 \cdot 5 \% \mathrm{FCS}$ & $947 \pm 37^{d}$ & $745 \pm 45^{b}$ & $1346 \pm 60^{c}$ & $2449 \pm 156^{\mathrm{c}}$ \\
\hline
\end{tabular}

Values are means \pm s.d. for the no. of observations in parentheses.

Mean concentrations of FSH or LH within the same culture condition that have the same superscript letter are not different, $P>0.05$.

* The media were adsorbed with $1.0 \%$ charcoal and $0.1 \%$ dextran before assay.

$\uparrow$ Pituitary cells incubated with $\mathrm{DMEM} \pm$ serum.

Ovarian-cell culture medium unsupplemented and supplemented with $2 \cdot 5 \%$ FCS did not significantly suppress the basal and LHRH-induced secretion of FSH. Protection of inhibin activity from adsorption by charcoal:dextran was first observed in basal conditions for the ovarian-cell medium supplemented with $5 \% \mathrm{FCS}$, and $7 \cdot 5,10.0$ and $12.5 \%$ FCS were effective for basal and LHRH-stimulated secretion of FSH. The ovarian-cell medium unsupplemented and supplemented with FCS did not significantly diminish the basal and the LHRH-induced release of LH.

In a second experiment, the protective effects of $10 \% \mathrm{FCS}$ and 1 or $2 \%$ BSA were compared. Inhibition of basal and the LHRH-stimulated secretion of FSH was absent for unsupplemented ovarian-cell medium adsorbed with charcoal : dextran. The presence of $10 \% \mathrm{FCS}$, and 1 and $2 \%$ BSA similarly prevented the adsorption of inhibin activity by charcoal : dextran. A dose-response protection for the ovarian-cell medium supplemented with BSA was statistically significant only during the LHRH-stimulated condition (data not shown).

To characterize further the protective effect of protein, the possibility of a temporal dependence of the protective effect of FCS on inhibin activity was examined. The medium from rat ovarian cells cultured in the absence of FCS was supplemented with $10 \%$ FCS immediately $(0 \mathrm{~min})$ before adsorption with $1.0 \%$ charcoal : $0.1 \%$ dextran at $15,30,45,60$ or $120 \mathrm{~min}$ or $24 \mathrm{~h}$ before being adsorbed by charcoal: dextran. The unsupplemented ovarian-ceil medium adsorbed by charcoal: dextran again had no effect on the secretion of FSH. The protective effect of FCS against the adsorption of inhibin by charcoal: dextran appeared to be instantaneous; the inhibition of basal and LHRH-stimulated FSH secretion by the ovarian-cell medium protected by FCS immediately 
before charcoal:dextran treatment was similar to the inhibition observed when ovarian-cell medium was exposed to FCS for a much longer period (data not shown).

\section{Validation of inhibin bioassay to rat ovarian-cell culture medium}

The inhibition curves of the inhibin reference standard (RTFS) and rat ovarian-cell culture medium adsorbed with $1.0 \%$ charcoal and $0.1 \%$ dextran were compared (Text-fig. 1 ).

Medium F10 + plus $10 \% \mathrm{FCS}$ had no effect on gonadotrophin secretion while the RTFS and the rat ovarian-cell culture medium suppressed the basal secretion of FSH and the LHRH-induced release of FSH and $\mathrm{LH}$ in a dose- and volume-responsive manner with a Finney's $\mathrm{g}$ for the inhibition curves $(0.011,0.007,0.024$ respectively) $<1$ (Borth, 1976). The slope of the inhibition curve of the basal secretion of FSH was steeper than that for the LHRH-induced release of FSH. The inhibitory activity on the basal secretion of FSH did not further increase after the addition of a dose of RTFS $>1.0 \mathrm{U}$ or a volume of ovarian cell medium $>62 \mu \mathrm{l}$.
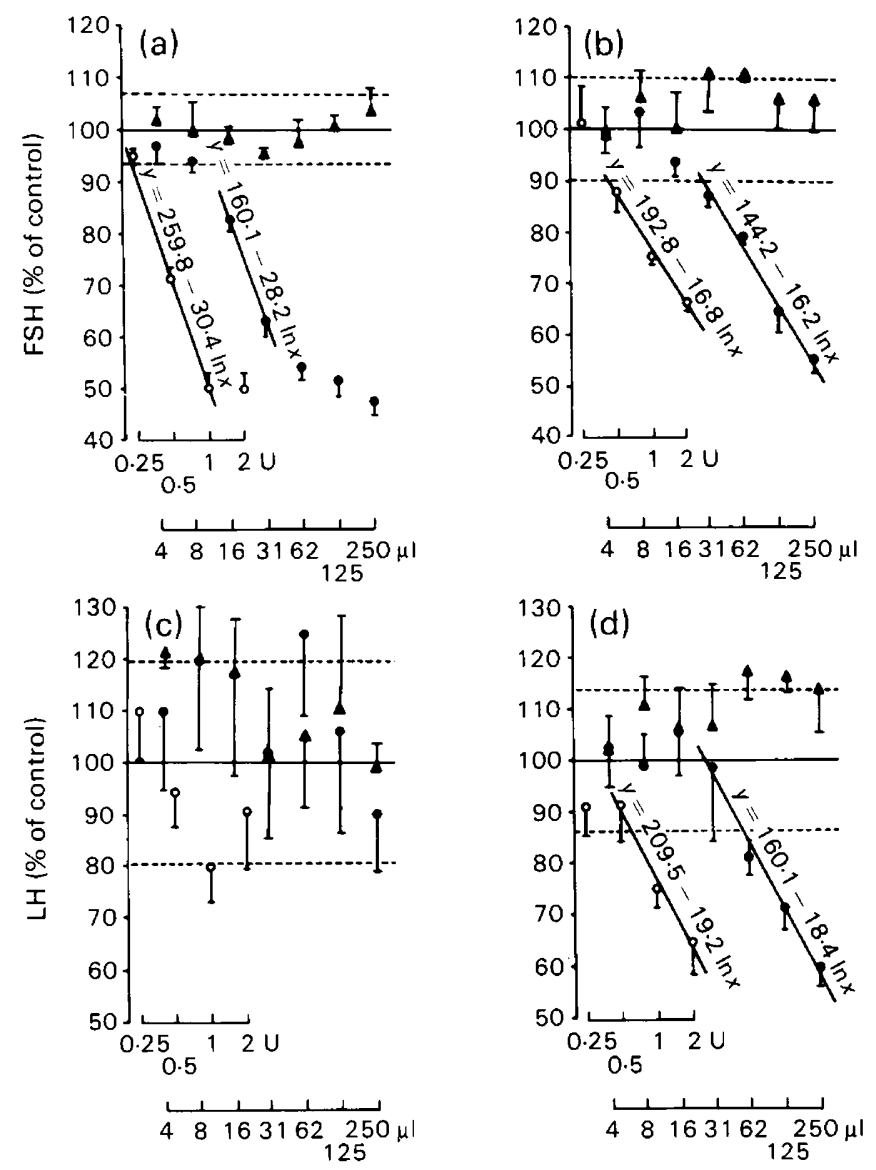

Text-fig. 1. Percentage of the control (mean \pm s.d., $n=4)$ of the secretion of FSH $(a, b)$ and LH (c, d) during the basal incubation ( $a, c)$ and in the presence of LHRH (b, d) from pituitary cells exposed to increasing doses $(0.25,0.5,1 \cdot 0,2 \cdot 0 \mathrm{U}, O)$ of the inhibin reference standard RTFS and to increasing volumes ( 4 to $250 \mu \mathrm{l}$ ) of culture medium unexposed ( $\boldsymbol{\Delta}$ ) or exposed $(\boldsymbol{O})$ to rat ovarian-cell medium adsorbed with $1.0 \%$ charcoal $: 0.1 \%$ dextran. The broken lines represent \pm 2 s.d. of the $100 \%$ control value. 
The response curve of the doses of inhibin standard and the volume of rat ovarian-cell culture medium were considered parallel between 0.25 and $1.0 \mathrm{U}$ and 16 and $31 \mu \mathrm{l}$ respectively during the basal secretion of FSH, and between 0.5 and $2.0 \mathrm{U}$ and 31 and $250 \mu \mathrm{l}$ during the LHRH-induced secretion of FSH and LH with the calculated $\mathrm{G}^{2}$ value non-significant at $P>0.05$. The lowest detectable amounts of inhibin (at -2 s.d. of the secretion of FSH in the absence of inhibin) were 0.24 and $0.46 \mathrm{U}$ for the basal and the LHRH-stimulated secretion of FSH, and $0.61 \mathrm{U}$ for the LHRH-induced release of $\mathrm{LH}$ with an index of precision $(\lambda)$ of $0.042,0.089$ and 0.17 respectively.

\section{Discussion}

Inhibin is a water-soluble substance of gonadal origin whose action on the secretion of gonadotrophins can be distinguished from the effect of gonadal steroids by its thermolability and its susceptibility to digestion by proteolytic enzymes (see review by Franchimont et al., 1979; de Jong, Jansen \& van der Molen, 1981). In the cultured pituitary-cell bioassay, the suppression of the gonadotrophic hormones by inhibin is usually characterized by a specific inhibition of the basal secretion of FSH and a preferential reduction of the secretion of FSH over that of LH in the presence of LHRH (de Jong, Welschen, Hermans, Smith \& van der Molen, 1978; de Jong, Smith \& van der Molen, 1979; Franchimont et al., 1979; Baker et al., 1981).

From our results, untreated rat ovarian-cell culture medium suppressed the secretion of FSH and LH in the basal and LHRH-stimulated condition (Table 1). This inhibition of the secretion of the gonadotrophic hormones by the untreated medium persisted after heating the culture medium at $80^{\circ} \mathrm{C}$ for $1 \mathrm{~h}$. This thermostable inhibitory action of the ovarian-cell culture medium may not be entirely caused by inhibin and could be due to the steroids present in the medium or to other thermostable substances contained in the medium.

The influence of the steroids on the secretion of the gonadotrophins was investigated by removing them by extraction with an organic solvent, ethyl acetate, or by adsorption with charcoal : dextran. Ethyl acetate removed $80 \%$ of the steroids but inhibition of the basal secretion of FSH and the LHRH-stimulated secretion of FSH and LH obtained with the ovarian-cell culture medium extracted with ethyl acetate was maintained or partly preserved after heating. This inhibitory activity could be due to the remaining androgens and oestrogens which are less well extracted by ethyl acetate than adsorbed by charcoal : dextran or to other substances not soluble in the organic solvent. Furthermore, a non-specific effect of the ethyl acetate treatment cannot be rejected since the extracted Medium F10 + plus 10\% FCS provoked variable interference of basal and LHRH-stimulated gonadotrophin secretion.

In conformity with the definition of inhibin, the rat ovarian-cell culture medium adsorbed with charcoal : dextran suppressed specifically the basal secretion of FSH and preferentially the LHRHinduced secretion of FSH over that of LH. This inhibitory effect was destroyed by heat. The effect of charcoal : dextran is probably exerted by the adsorption of steroids, especially androgens and oestrogens whose concentrations are at the limit of the detection of the radioimmunoassay after adsorption with $1 \cdot 0 \%$ charcoal $: 0 \cdot 1 \%$ dextran (Table 2 ).

It is known that steroids can act on the secretion of FSH. A stimulatory effect on the basal secretion of FSH has been observed for progesterone (Erickson \& Hsueh, 1978; Labrie et al., 1978; Drouin \& Labrie, 1981), androgens and oestradiol (Steinberger \& Chowdhury, 1974; Labrie et al., 1978; de Jong et al., 1979), but an inhibitory action was described for androgens (Lee et al., 1979) and no effect for oestradiol (Drouin \& Labrie, 1981). These variable effects of steroids on the basal secretion of FSH could explain the fact that the inhibition caused by charcoal : dextran adsorption of ovarian-cell culture medium when most of the steroids are removed is greater, smaller or similar to the suppression exerted by the untreated medium. The concentration and the ratio of the various types of steroids could be important determinants of the effectiveness. Shander et al. (1980) found that the $67 \%$ inhibition of the basal secretion of FSH by porcine follicular fluid adsorbed with 
charcoal : dextran was diminished by $\sim 50 \%$ when combined with oestradiol $\left(10^{-8} \mathrm{M}\right)$, testosterone $\left(10^{-7} \mathrm{M}\right)$ and progesterone $\left(10^{-7} \mathrm{M}\right)$.

Contrary to the responses in basal conditions, the inhibition of the release of FSH and LH induced by LHRH was always significantly greater for the untreated ovarian-cell medium and was probably linked to the presence of androgens (present study; Croze \& Franchimont, 1984). Androgens have been known to enhance the inhibitory activity of charcoal :dextran-adsorbed bull seminal plasma in vivo (Peek \& Watkins, 1980) and porcine follicular fluid in vitro (Lagace et al., 1979). Baker et al. (1978), Labrie et al. (1978) and Eddie, Baker, Higginson \& Hudson (1979) found that androgens decrease the LHRH-induced release of FSH and LH. This effect of androgens could be related to a decrease in the LHRH-binding sites (Giguere, Lefevre \& Labrie, 1981). In spite of those findings, androgens have also been reported to have no effect (de Jong et al., 1979) or to increase (Lee et al., 1979) the LHRH-stimulated secretion of FSH.

Although the treatment by charcoal :dextran appears to be the best method to eliminate the steroids in the culture medium, inhibin can also be adsorbed by percentages of charcoal: dextran greater than 1.0:0 1. Our observations corroborate well the results of Baker et al. (1978) who recovered $94 \%$ of the inhibin activity after adsorption of ovine testicular lymph. Tsonis et al. (1983) observed a decrease in the inhibitory activity of ovine follicular fluid diluted with Medium 199 after treatment with $1.0 \%$ charcoal : $0.1 \%$ dextran, but there was no statistical difference between the inhibin activity measured for the unadsorbed follicular fluid and the fluid adsorbed with $0 \cdot 05: 0.005 \%$ and $0 \cdot 1: 0 \cdot 01 \%$ charcoal: dextran.

The loss of inhibitory activity was also found for the serum-free ovarian-cell culture media adsorbed with only $1.0 \%$ charcoal $: 0 \cdot 1 \%$ dextran. This adsorption of inhibin by charcoal : dextran can be prevented by the addition of $10 \%$ FCS or with a concentration of 1 or $2 \%$ BSA which is within the normal serum range (Price \& Gregory, 1982). The protective effect of FCS can be recognized from the results presented by Henderson \& Franchimont (1981). Nevertheless, inhibin activity has been measured in serum-free Sertoli-cell culture medium adsorbed by charcoal:dextran (Franchimont, Croze \& Verhoeven, 1980) although the presence of 50-80\% of Sertoli-cell culture medium was required with the pituitary cells to produce an inhibitory effect. The protective effect does not depend on the time of exposure of the rat ovarian-cell culture medium to the FCS and implies that serum proteins act as a charcoal-coater to prevent the adsorption of inhibin. In the absence of serum, rat ovarian cells produce some inhibin but serum is necessary for quantitative production of inhibin (Croze \& Franchimont, 1984).

The rat ovarian-cell culture medium adsorbed with $1.0 \%$ charcoal and $0.1 \%$ dextran has an inhibition curve similar to that of the inhibin reference standard (RTFS) but the relative potency of the ovarian-cell culture media is slightly lower in the presence of LHRH than in basal conditions. Baker et al. (1981) and de Jong et al. (1983) have also noticed differences in relative inhibitory potency of test materials as compared to their standard in the various endpoints of the pituitary-cell in-vitro biological assay. Baker et al. (1981) suggested that these inhibitory effects are caused by different substances. It is also possible that two different actions of inhibin are tested in the two conditions of the biological assay: (1) an action on the synthesis of FSH during the basal incubation, and (2) a cumulative effect of inhibin on the synthesis and the relase of FSH induced by LHRH.

The index of precision in the present study for LHRH-stimulated FSH secretion was similar to that usually reported (de Jong et ai., 1979; Hudson et al., 1979; Baker et al., 1981; Henderson \& Franchimont, 1981) but better than that reported by de Jong et al. (1978, 1979), Baker et al. (1981) and Henderson \& Franchimont (1981) for basal conditions. Concomitantly, we obtained a greater sensitivity and a higher significance of regression (Finney's g) in the basal condition than in the LHRH-stimulated situation with the RTFS. This is contradictory to the better sensitivity measured in the LHRH-stimulated condition for the OTLP6 (Henderson \& Franchimont, 1981) and the $\mathrm{RTF}_{38}$ (Franchimont et al., 1979) preparations and does not corroborate the lack of reliability of the inhibin in-vitro bioassay for the inhibition of the basal secretion of FSH found by Baker et al. 
(1976), Eddie, Baker, Dulmanis, Higginson \& Hudson (1978) and Eddie et al. (1979). The origin and the purity of the different standards used are probably the cause of these discrepancies.

F.C. is a recipient of a Belgian-Canadian exchange fellowship. We thank Professor B. Hudson (Howard Florey Institute of Experimental Physiology and Medicine, University of Melbourne, Australia) for the RTFS; the NIAMDD for the rat pituitary gonadotrophin reagents; Dr F. Ectors, (Faculté de Médecine Vétérinaire, Université de Liège, Belgium) for the ovine FSH antiserum; Professor U. Rosa (Laboratorio de Fisiologia Clinica, University of Pisa, Italy) for the progesterone antiserum; Dr R. J. Etches (Department of Animal Science, University of Guelph, Canada) for the testosterone and oestradiol antisera; Mr M. McNamara for help with the English of the manuscript; and Mrs S. Pregaldien and Mrs J. McDougald for their care and patience with the typing.

This research was supported by grants No. 3.4501.81 of the Belgian Foundation for Medical Research (FRSM).

\section{References}

Baker, H.W.G., Bremner, W.J., Burger, H.G., de Kretser, D.M., Dulmanis, A., Eddie, L.W., Hudson, B., Keogh, E.J., Lee, V.W.K. \& Rennie, G.C. (1976) Testicular control of follicle-stimulating hormone secretion. Recent Prog. Horm. Res. 32, 429-476.

Baker, H.W.G., Burger, H.G., de Kretser, D.M., Eddie, L.W., Higginson, R.E., Hudson, B. \& Lee, V.W.K. (1978) Studies on purification of inhibin from ovine testicular secretions using an in-vitro bioassay. Int. $J$. Androl., Suppl. 2, 115-124.

Baker, H.W.G., Eddie, L.W., Higginson, R.E., Hudson, B., Keogh, E.J. \& Niall, H.D. (1981) Assays of inhibin. In Intragonadal Regulation of Reproduction, pp. 193-228. Eds P. Franchimont \& C. P. Channing. Academic Press, London.

Borth, R. (1976) Statistic of parallel-line assay. In Methods of Hormone Analysis, pp. 500-513. Eds H. Breuer, D. Hamel \& H. L. Kruskemper. Georg Thieme Verlag, Stuggart.

Campbell, C.S. \& Schwartz, N.B. (1979) Time course of serum FSH suppression in ovariectomized rats injected with porcine follicular fluid (folliculostatin). Effect of estradiol treatment. Biol. Reprod. 20, 10931098.

Croze, F. \& Franchimont, P. (1984) An in-vitro model for the study of inhibin production by rat ovarian cells. $J$. Reprod. Fert. 72, 249-260.

de Jong, F.H., Welschen, R., Hermans, W.P., Smith, S.D. \& van der Molen, H.J. (1978) Effects of testicular and ovarian inhibin-like activity using in-vitro and invivo systems. Int. J. Androl., Suppl. 2, 125-138.

de Jong, F.H., Smith, S.D. \& van der Molen, H.J. (1979) Bioassay for inhibin-like activity using pituitary cells in vitro. J. Endocr. 80, 91-102.

de Jong, F.H., Jansen E.H.J.M. \& van der Molen, H.J. (1981) Purification and characterization of inhibin. In Intragonadal Regulation of Reproduction, pp. 229250. Eds P. Franchimont \& C. P. Channing. Academic Press, London.

de Jong, F.H., Jansen, E.H.J.M., Steenbergen, J., van Dijk, S. \& van der Molen, H.J. (1983) Assay and purification of inhibin. In Role of Peptides and
Proteins in Control of Reproduction, pp. 257-273. Eds S. M. McCann \& D. S. Dhindsa. Elesevier Biochemical, Amsterdam.

Derivaux, J., Ectors, F., Hendrick, J.C. \& Franchimont, P. (1974) Determination de la FSH plasmatique chez les bovins. Annls Endocr. 35, 614-621.

Drouin, J. \& Labrie, F. (1981) Interactions between 17 oestradiol and progesterone in the control of the luteinizing hormone and follicle-stimulating hormone release in rat anterior pituitary cells in culture. Endocrinology 108, 52-57.

Eddie, L.W., Baker, H.W.G., Dulmanis, A., Higginson, R.E. \& Hudson, B. (1978) Inhibin from cultures of rat seminiferous tubules. $J$. Endocr. 78, 217-224.

Eddie, L.W., Baker, H.W.G., Higginson, R.E. \& Hudson, B. (1979) A bioassay for inhibin using pituitary cell cultures. $J$. Endocr. 81, 49-60.

Erickson, G.F. \& Hsueh, A.J.W. (1978) Secretion of inhibin by rat granulosa cells in vitro. Endocrinology 103, 1960-1963.

Franchimont, P., Verstraelen-Proyard, J., Hazee-Hagelstein, M.T., Renard, Ch., Demoulin, A., Bourguignon, J.P. \& Hustin, J. (1979) Inhibin: from concept to reality. Vitams Horm. 37, 243-302.

Franchimont, P., Croze, F. \& Verhoeven, G. (1980) Augmentation simultanée de l'aromatization de la testostérone en oestrogènes et de la sécrétion d'inhibine par les cellules de Sertoli en culture. C. r. Séanc. Soc. Biol. 174, 893-897.

Giguere, V., Lefevre, F.A. \& Labrie, F. (1981) Androgens decrease LHRH binding sites in rat anterior pituitary cells in culture. Endocrinology 108, 350-352.

Greenwood, F., Hunter, W. \& Glover, S. (1963) Preparation of ${ }^{131}$ I-labelled human growth hormone of high specific radioactivity. Biochem. J. 89, 114-123.

Henderson, K.M. \& Franchimont, P. (1981) Regulation of inhibin production by bovine ovarian cells in vitro. $J$. Reprod. Fert. 63, 431-442.

Henderson, K.M. \& Franchimont, P. (1983) Inhibin production by bovine ovarian tissues in vitro and its regulation by androgen. $J$. Reprod. Fert. 67, 291298. 
Hermans, W.P., van Leeuwen, E.C.M., Debets, M.H.M., Sander, H.J. \& de Jong, F.H. (1982) Estimation of inhibin-like activity in spent medium from rat ovarian granulosa cells during long-term culture. Molec. cell. Endocr. 27, 277-290.

Hudson, B., Baker, H.W.G., Eddie, L.W., Higginson, R.E., Burger, H.G., de Kretser, D.M., Dobos, M. \& Lee, V.W.K. (1979) Bioassay for inhibin: a critical review. J. Reprod. Fert., Suppl. 26, 17-29.

Labrie, F., Lagace, L., Ferland, L., Kelly, P.A., Drouin, J., Massicotte, J., Bonne, C., Raynaud, J.P. \& Dorrington, J.H. (1978) Interactions between LHRH, sex steroids and inhibin in the control of $\mathrm{LH}$ and FSH secretion. Int. J. Androl., Suppl. 2, 81-101.

Lagace, L., Massicotte, J., Drouin, J., Giguere, V., Dupont, A. \& Labrie, F. (1979) Interaction between luteinizing hormone releasing hormone and inhibin at the pituitary level in the control of luteinizing hormone and follicle stimulating hormone secretion in the rat. In Recent Advances in Reproduction and Regulation of Fertility, pp. 73-85. Ed. G. P. Talwar. Elsevier/North Holland Biomedical Press, Amsterdam.

Lee, V.W.K., Scott, R.S., Dobos, M., Zachariah, E., de Kretser, D.M. \& Burger, H.G. (1979) Inhibin and the biological significance of FSH suppression. In Recent Advances in Reproduction and Regulation of Fertility, pp. 241-251. Ed. G. P. Talwar. Elsevier/North Holland Biomedical Press, Amsterdam.

Miller, K.F., Wesson, J.A. \& Ginther, O.J. (1981) Interaction of estradiol and a nonsteroidal follicular fluid substance in the regulation of gonadotropin secretion in the mare. Biol. Reprod. 24, 354-358.

Peek, J.C. \& Watkins, W.B. (1980) Synergism between bovine seminal plasma extract and testosterone propionate in suppressing serum concentrations of gonadotrophins in acutely castrated rats: a role for inhibin. J. Endocr. 86, 349-355.

Pollard, J.H. (1977) A Handbook of Numerical and Statistical Techniques, 1st edn, pp. 175-177. Cambridge University Press, Cambridge.

Price, P.J. \& Gregory, E.A. (1982) Relationship between in vitro growth promotion and biophysical and biochemical properties of the serum supplement. In Vitro 18, 576-584.

Rush, M.E., Ashiru, O.A., Lipner, H., Williams, A.T., McRae, C. \& Blake, C.A. (1981) The actions of porcine follicular fluid and estradiol on peri-ovulatory secretion of gonadotropic hormones in rats. Endocrinology 108, 2316-2323.

Shander, D., Anderson, L.D., Barraclough, C.A. \& Channing, C.P. (1980) Interactions of porcine follicular fluid with ovarian steroids and luteinizing hormone-releasing hormone on the secretion of luteinizing hormone and follicle-stimulating hormone by cultured pituitary cells. Endocrinology 106, 237-242.

Steel, R.G.D. \& Torrie, J.H. (1960) Principles and Procedures of Statistics. McGraw-Hill, New York.

Steinberger, A. \& Chowdhury, M. (1974) Effect of testosterone and estradiol on the basal and LRFstimulated secretion of gonadotropins in pituitary cell culture. Endocr. Res. Commun. 1, 389-401.

Tsonis, C.G., Quigg, H., Lee, V.W.K., Leversha, L., Trounson, A.O. \& Findlay, J.K. (1983) Inhibin in individual ovine follicles in relation to diameter and atresia. J. Reprod. Fert. 67, 83-90.

Williams, A.T. \& Lipner, H. (1980) Serum gonadotropin response to chronic treatment with oestrogen and porcine follicular fluid in the ovariectomized rat. Fedn Proc. Fedn Am. Socs exp. Biol. 39, 822, Abstr.

Received 13 October 1983 